\title{
An Analysis of Consumer Evaluations of the "Tagonoura Shirasu" Certification under the Japan Geographical Indication Protection System
}

\author{
Yu-Heng Lu \\ Department of Environmental Biology and Fisheries Science, National Taiwan Ocean University, 2, Pei-Ning Rd., \\ Keelung, Taiwa, yhlu@mail.ntou.edu.tw \\ Takahiro Sajiki \\ National Research Institute of Fisheries Science, Japan Fisheries Research and Education Agency, 2-12-4 Fukuura, \\ Kanazawa, Yokohama, Japan
}

Follow this and additional works at: https://jmstt.ntou.edu.tw/journal

Part of the Fresh Water Studies Commons, Marine Biology Commons, Ocean Engineering Commons, Oceanography Commons, and the Other Oceanography and Atmospheric Sciences and Meteorology Commons

\section{Recommended Citation}

Lu, Yu-Heng and Sajiki, Takahiro (2021) "An Analysis of Consumer Evaluations of the "Tagonoura Shirasu" Certification under the Japan Geographical Indication Protection System," Journal of Marine Science and Technology. Vol. 29: Iss. 4, Article 10.

DOI: $10.51400 / 2709-6998.1590$

Available at: https://jmstt.ntou.edu.tw/journal/vol29/iss4/10

This Research Article is brought to you for free and open access by Journal of Marine Science and Technology. It has been accepted for inclusion in Journal of Marine Science and Technology by an authorized editor of Journal of Marine Science and Technology. 


\title{
An Analysis of Consumer Evaluations of the "Tagonoura Shirasu" Certification under the Japan Geographical Indication Protection System
}

\author{
Yu-Heng $\mathrm{Lu}^{\mathrm{a}, *}$, Takahiro Sajiki ${ }^{\mathrm{b}}$ \\ ${ }^{a}$ Department of Environmental Biology and Fisheries Science, National Taiwan Ocean University, 2, Pei-Ning Rd., Keelung, 20224, \\ Taiwan \\ ${ }^{\mathrm{b}}$ Fisheries Technology Institute, Japan Fisheries Research and Education Agency, 2-12-4 Fukuura, Kanazawa, Yokohama, Kanagawa \\ 2368648, Japan
}

\begin{abstract}
Over time, the Geographical Indication (GI) protection system has been independently adopted in more than 100 countries worldwide. In Japan, the GI protection system has been operating since 2015 in response to a growing interest in local brands. Therefore, based on a questionnaire survey, we econometrically analyze the consumer evaluation of Shizuoka Prefecture's Shirasu "Tagonoura Shirasu," which is registered under the GI protection system. Shirasu is a collective term for long and narrow larvae such as anchovy (Engraulis japonicus), sardine (Sardinops melanostictus), or red-eye round herring (Etrumeus sadina). Based on the contingent valuation method, we clarified that consumers' additional willingness to pay (WTP) for Tagonoura Shirasu was approximately $8.2 \%$ compared to the Shirasu produced in Shizuoka Prefecture, which has not been certified under the GI protection system. Moreover, eight characteristics of consumers with a high WTP were revealed: they have purchased Shirasu within the last year, attach importance to freshness when buying seafood, have a greater awareness of regional production standards when purchasing seafood, purchase foodstuffs linked to the revitalization of production areas and regions, show little regard for buying products as cheaply as possible when purchasing foodstuffs, know about the GI protection system in greater detail, are male, and have a high annual household income. To further enhance the economic value of Tagonoura Shirasu, it would be effective to target consumers with all eight characteristics for a high WTP.
\end{abstract}

Keywords: Geographical indication, Tagonoura Shirasu, Consumer evaluation, Japan

\section{Introduction}

$\mathrm{L}$ ocal brand initiatives are gaining increasing attention in Japan [1]. Regional brand initiatives are expected to contribute to the revitalization of regional economies by differentiating products from those of other regions and improving the local image by increasing the added value. However, as consumers' evaluations of a regional brand improve, so do the probability of damage to that evaluation and trust due to third parties free riding on those regional brands. The need for appropriate legal protection for regional brands in Japan has been thus pointed out.

Therefore, in April 2006, a law partially amending the Trademark Act was implemented for trademark registration during the early stages of regional brand development, and the regional collective trademark system was launched. The regional collective trademark system is a system by which a trademark consisting of a region name and a product (service) name can be registered. That said, under the regional collective trademark system,

* Corresponding author. Department of Environmental Biology and Fisheries Science, National Taiwan Ocean University, 2, Pei- 
product manufacturing methods and quality standards are voluntary and efforts to identify the unauthorized use of trademarks are to be made by the trademark holders themselves, while international trademark registrations must be made individually for each country (Table 1 ).

The operation of the Geographical Indication (GI) protection system in Japan begun in June 2015 [2]. As of November 2019, 86 products have been registered, including nine marine industry products. The GI protection is a system by which geographical indications can be registered nationally as intellectual property: for agricultural, forestry, and fishery products possessing characteristics and traditions developed in a particular region and where quality and social regard are linked to the production area, a name is assigned to identify that link [3]. Unlike the regional collective trademark system, under GI protection system, the method of production and quality standards must be registered and adhered to (Table 1). Moreover, the state will act against the unauthorized use of certified products. Furthermore, when mutual protection is implemented between countries with GI protection systems, the registered products will also be protected in those countries.

Table 1. Differences between the GI protection system and the regional collective trademark system.

\begin{tabular}{|c|c|c|}
\hline Item & GI protection system & Regional collective trademark system \\
\hline Overview & $\begin{array}{l}\text { Protected as an asset shared across an area. Pro- } \\
\text { tection for the name of products that have char- } \\
\text { acteristics linked to the region. }\end{array}$ & $\begin{array}{l}\text { Protection as a property (right) of the local orga- } \\
\text { nization. Protection for names which are well- } \\
\text { known for their use by local organizations. }\end{array}$ \\
\hline Name & $\begin{array}{l}\text { If the area is specific, the name of the place need } \\
\text { not be included. }\end{array}$ & "Area name" + "Product name," etc. \\
\hline Subject of protection & $\begin{array}{l}\text { 1. All edible agriculture, forestry, and fishery } \\
\text { products. } \\
2.13 \text { items*, namely agricultural, forestry, and } \\
\text { fishery products not for consumption. } \\
\text { 3. Products such as alcoholic beverages, pharma- } \\
\text { ceuticals, quasi-drugs, cosmetics, and regenera- } \\
\text { tive medical products are excluded. }\end{array}$ & All products and services. \\
\hline Registered entity & $\begin{array}{l}\text { A group of producers or processors (non-corpo- } \\
\text { rate groups are also acceptable). }\end{array}$ & $\begin{array}{l}\text { Agricultural cooperative associations, societies of } \\
\text { commerce, chambers of commerce and industry } \\
\text { Restricted to NPO corporations. }\end{array}$ \\
\hline Destination of application & Ministry of Agriculture, Forestry and Fisheries. & Japan Patent Office \\
\hline Key registration requirements & $\begin{array}{l}\text { 1. Possessing characteristics such as quality } \\
\text { associated with the area of production. } \\
\text { 2. Have a track record of continued production } \\
\text { over a certain period (approximately } 25 \text { years). }\end{array}$ & $\begin{array}{l}\text { 1. There is a relationship between the name of } \\
\text { region and the product. } \\
\text { 2. The trademark is widely known among } \\
\text { consumers. }\end{array}$ \\
\hline Quality control & $\begin{array}{l}\text { Yes. Registration of methods of production and } \\
\text { standards of quality for the product, the subse- } \\
\text { quent addition of producer groups is also } \\
\text { possible. }\end{array}$ & $\begin{array}{l}\text { None. Producer standards are optional (may be } \\
\text { freely set and changed), usage rights can be set } \\
\text { arbitrarily. }\end{array}$ \\
\hline Efficacy & $\begin{array}{l}\text { Prohibition of the unauthorized use of } \\
\text { geographical indications and other similar marks. }\end{array}$ & $\begin{array}{l}\text { Prohibition of the unauthorized use of the regis- } \\
\text { tered trademark and other similar trademarks. }\end{array}$ \\
\hline Regulatory measures & Government controlled. & Rights to be exercised by the individual. \\
\hline Protection overseas & $\begin{array}{l}\text { When mutual protections are implemented be- } \\
\text { tween two countries with geographical indication } \\
\text { protection systems, these will be protected in both } \\
\text { countries. }\end{array}$ & To be registered in each country individually. \\
\hline Cost and protection period & $\begin{array}{l}\text { Registration license fee: } 90,000 \text { yen. } \\
\text { Protection period: Registered period. }\end{array}$ & $\begin{array}{l}\text { Application fee: } 3400 \text { yen }+ \text { (number of } \\
\text { categories } \times 8600 \text { yen). } \\
\text { Registration fee: Number of categories } \times 28,200 \\
\text { yen. } \\
\text { Protection period: } 10 \text { years. }\end{array}$ \\
\hline Update & $\begin{array}{l}\text { No procedure. } \\
\text { No renewal fee required. }\end{array}$ & $\begin{array}{l}\text { Procedures in place. Renewal fee: Number of } \\
\text { categories } \times 38,800 \text { yen. }\end{array}$ \\
\hline
\end{tabular}

Note: *The 13 items are ornamental plants, craft agricultural products, bamboo groves, ornamental fish, pearls, feed (limited to those produced or processed using agricultural, forestry, and fishery products as raw material), lacquer, bamboo, wood, charcoal, volatile oils, tatami mats, and raw silk.

Source: The Ministry of Agriculture, Forestry and Fisheries, compiled from "What is Geographic Indication Labeling?" (http://www. maff.go.jp/j/shokusan/gi_act/outline/index.html) and Japan Patent Office, "The Regional Collective Trademark System" (https://www. jpo.go.jp/system/trademark/gaiyo/chidan/t_dantai_syouhyou.html). 
The [2] states that the GI protection systems aims to protect producers' interests by protecting local brands and points out that for the registration under GI for agricultural products, the following are evident: 1) counterfeit elimination, 2) increased trade, 3) increased supporters, and 4) increased price effects. However, a limited period of time has passed since the beginning of the operation of the GI protection system in Japan, and how consumers evaluate GI registered marine products is not yet necessarily fully understood.

The GI protection system is positioned as a form of intellectual property under the Agreement on TradeRelated Aspects of Intellectual Property Rights (TRIPS), one of the annexes of the WTO Agreement, and has been hitherto independently adopted in more than 100 countries [2]. For instance, the European Union introduced a standardized protection system in 1992. Europe has a history and track record of GI protection [4], and research on consumer evaluations of the GI protection system and products registered under GI protection systems is still ongoing [5]. Extant studies analyze the characteristics of consumers with a high awareness of the GI protection system and the characteristics of consumers highly motivated to purchase products registered under this system $[6,7]$. Concerning the economic value of products registered in the GI protection system [8], classify products according to consumer awareness and whether they target foreign or domestic markets, and show the effects of price increases. Moreover, among GI protection systems, the strictly administered certification "Protected Designation of Origin" has a higher price premium than the loosely administered certification "Protected Geographical Indication" [9]. Further, the impact of different meat pieces on consumers' willingness to pay (WTP) has been analyzed [10]. As to the economic value of marine products registered in a GI protection system, the price premium of oysters [6] and of marine products as a whole is lower than those of other products [11]. [12] points out that products registered under a GI protection system can lead to the development of the tourism industry, which can be expected to revitalize the local economy.

However, few studies consider consumer awareness and intent regarding the Japanese GI protection system. To date, virtually no studies have analyzed how highly consumers evaluate marine products registered under the Japanese GI protection system, nor the characteristics of consumers who evaluate these marine products highly. In Japanese fisheries policy, the 2017 Basic Fisheries Plan promotes the efforts to protect the brand value of high-quality marine products by using the GI protection system [13].

Therefore, we clarify consumers' valuation of Shizuoka Prefecture's "Tagonoura Shirasu," which was registered under Japan's GI protection system in 2017 (Fig. 1). Specifically, based on a survey of

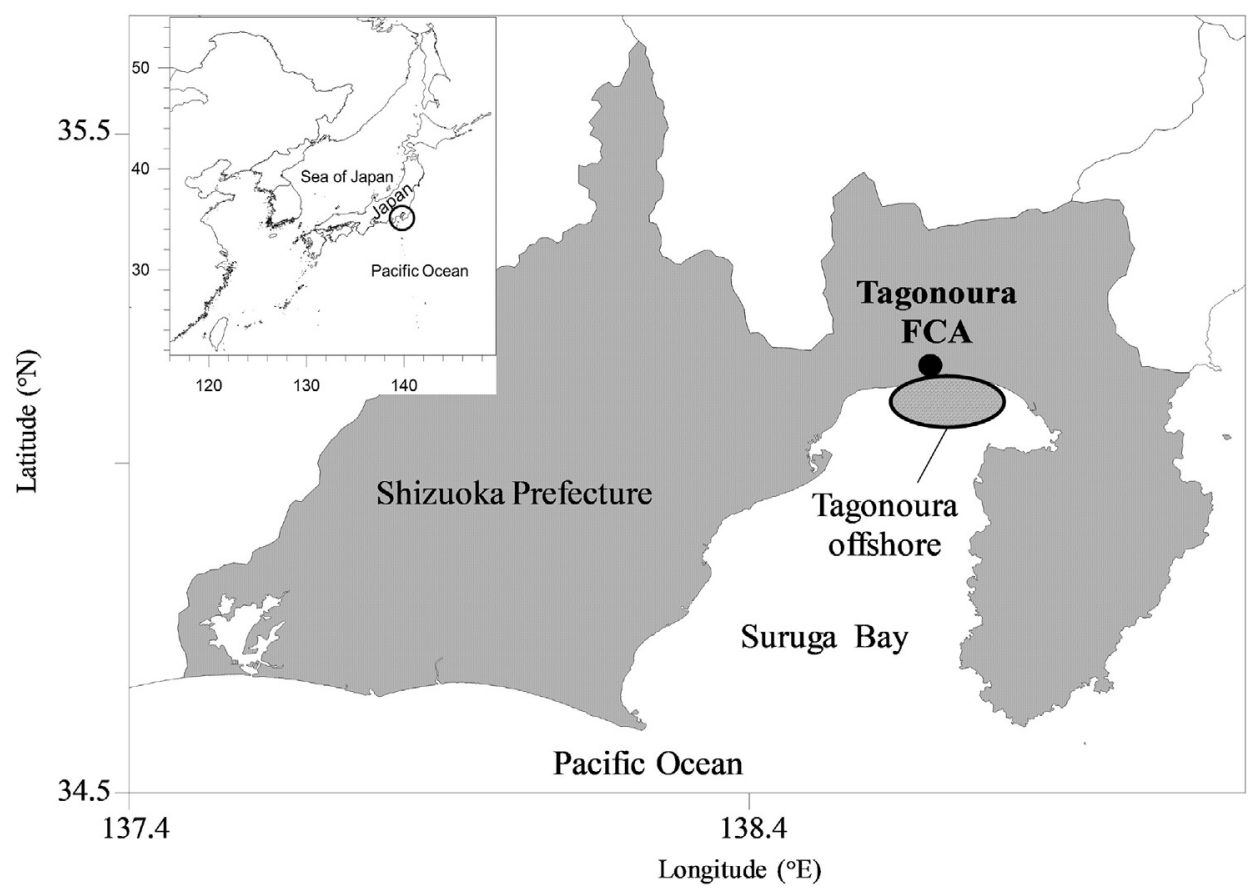

Fig. 1. Tagonoura fishery cooperative association and Tagonoura Shirasu's fishing ground. 
Table 2. Production methods for Tagonoura Shirasu.

\begin{tabular}{|c|c|c|c|}
\hline Item & & & Content \\
\hline Fishing ground & & & $\begin{array}{l}\text { Off Tagonoura, Shizuoka Prefecture (Off the coasts of Fuji } \\
\text { City and Numazu City) }\end{array}$ \\
\hline \multirow[t]{4}{*}{ Fishing method } & 1. Fishing method & & Shirasu single boat seine fishing \\
\hline & 2. Freshness management & 1) Use of colanders & $\begin{array}{l}\text { Immediately after catching the fish, the Shirasu is transferred } \\
\text { to a colander to drain the water in the ship. }\end{array}$ \\
\hline & & 2) Ice packing work & $\begin{array}{l}\text { A large quantity of ice is placed among the Shirasu that has } \\
\text { been transferred to the colander, and stirred by hand to } \\
\text { prevent damage to the Shirasu. }\end{array}$ \\
\hline & & 3) Prompt unloading & $\begin{array}{l}\text { Prompt return to port after fishing, and directly unloading at } \\
\text { the market without being left in high-temperature locations } \\
\text { for any length of time }\end{array}$ \\
\hline Landing port & & & Tagonoura Port, Fuji City, Shizuoka Prefecture \\
\hline Final product form & & & Fresh fish \\
\hline
\end{tabular}

Source: Compiled from [17].

consumers in Japan's major consumer areas, the Kanto and Kansai regions, along with measuring the economic value of Tagonoura Shirasu, we present the characteristics of consumers who regard its economic value to be high. To this end, we apply the contingent valuation method (CVM) to clarify the additional WTP permissible to consumers, as well as the consumer characteristics that affect the WTP $(\%)$ for Tagonoura Shirasu compared to Shizuoka Prefecture, where Shirasu that has not been certified under the GI protection system.

Shirasu is caught throughout Japan, the main catch areas being the Pacific coast below Fukushima Prefecture and the Kyushu west coast that faces the East China Sea and the Seto Inland Sea [14]. Shirasu is not the name of a fish, but rather a general term for fish that have extremely poor chromatophores in their early developmental stages, often referring to long and narrow larvae such as anchovy (Engraulis japonicus), sardine (Sardinops melanostictus), and redeye round herring (Etrumeus sadina) $[15,16]$. The forms in which Shirasu is consumed are raw, boiled, and dried. Where sufficiently fresh, it is eaten raw. Salted Shirasu is used for boiled Shirasu, while dried Shirasu is prepared either by using a hot air dryer or sun-drying treatment.

Shizuoka Prefecture ranks second in terms of Shirasu production in Japan. It accounted for $14.1 \%$ $(8,905$ tons) of the Japanese Shirasu production in 2016 (63,180 tons) [14]. Tagonoura Shirasu represents only $1.7 \%$ (147 tons) of Shizuoka Prefecture's production $(8,905$ tons) [17]. Understanding its valuation by consumers from Japan's main consumer regions, Kanto and Kansai, is expected to be highly significant to expanding the sales channels for Tagonoura Shirasu outside of Shizuoka Prefecture and investigating value-added sales.

\section{Materials and methods}

\subsection{Tagonoura Shirasu ${ }^{1}$}

The Tagonoura Fishery Cooperative in Shizuoka Prefecture is the registered producer group for Tagonoura Shirasu under the GI protection system. Tagonoura Shirasu specifies everything from the fishing grounds to the final form of the product (Table 2). The fishing ground is off the coast of Tagonoura, within 30 min of Tagonoura Port (Fig. 1., [17]. It also specifies how to manage freshness, such as methods of fishing and ice packing following the catch. The landing site is only Tagonoura Port and the final product is fresh fish.

The fishing ground off Tagonoura can only be used by one ship at a time due to the steep terrain. However, since only small quantities can be caught by a single boat, Shirasu can be caught without harm. Moreover, because the fishing ground is close and the production methods for freshness management are also specified, even thawed raw Shirasu have a texture almost indistinguishable from freshly caught Shirasu. Boiled Shirasu is salted and bent at the neck, being plump and shaped like the letter $\mathrm{L}$, and has a strong umami flavor.

Due to the freshness and qualities cited above, the average price for Tagonoura Shirasu at the time of

\footnotetext{
${ }^{1}$ Mainly compiled with reference to public registration notice no. 36 (http://www.maff.go.jp/j/shokusan/gi_act/register/36.html).
} 


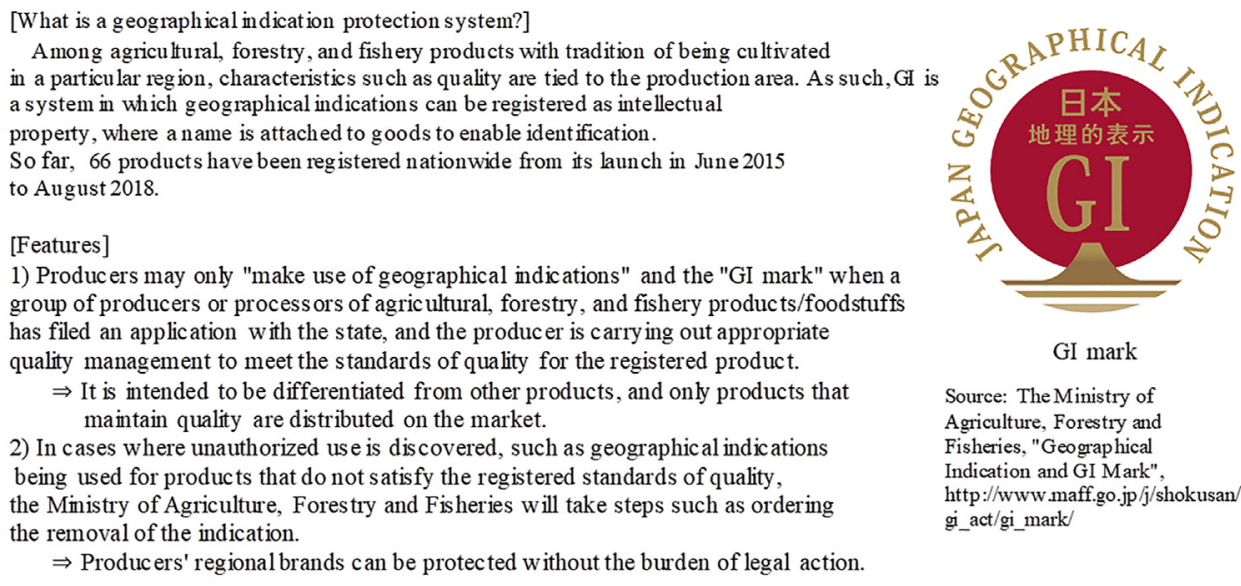

GI mark

Source: The Ministry of A griculture, Forestry and Fisheries, "Geographical Indication and GI Mark", http://www.maff.go.jp/j/shokusan/ gi_act/gi_mark/

Fig. 2. Explanation of the GI protection system in the survey.

landing between 2007 and 2016 was 694 yen $/ \mathrm{kg}$, trading at 128 yen $/ \mathrm{kg}$ above the average price at six ports within Shizuoka Prefecture, that is, at 556 yen/ $\mathrm{kg}$. Recently, distributors and processors in nearby Shirasu producing areas within Shizuoka Prefecture have begun purchasing Shirasu from Tagonoura. The average price at the time of landing for Tagonoura Shirasu in 2016 was 923 yen/kg and it received good reviews.

\subsection{Consumer questionnaire}

For the consumer questionnaire, in October 2018, internet research was conducted by a survey research company. The targets of the survey were assumed to be consumers who had the potential to become purchasers, being over 20 years old and the main person purchasing seafood in their household. Target regions for the survey were six prefectures and one metropolis in the Kanto region (Tokyo, Kanagawa, Saitama, Chiba, Ibaraki, Tochigi, and Gunma prefectures) and four prefectures and two metropolises in the Kansai region (Osaka, Kyoto, Hyogo, Shiga, Nara, and Wakayama prefectures), which are the major consumption areas in Japan. Data were collected according to the population distribution by age bracket and prefecture.

In the survey, in addition to awareness and behavior when purchasing foods and personal attributes, questions about the GI protection system and CVM were also included. Among the questions concerning the GI protection system and CVM, the GI mark was first shown and an overview of the GI protection system given, with its characteristics explained (Fig. 2). Additionally, a photograph of Tagonoura Shirasu was presented, and an overview of Tagonoura Shirasu's production area, product characteristics, links to the region, etc. given (Fig. 3).
Next, a hypothetical situation was presented to the respondent: "Suppose that two types of boiled Shirasu packs are now being sold at the fishmonger's counter at the supermarket, completely identical in freshness, appearance, taste, and weight. The first is boiled Shirasu certified as Tagonoura Shirasu under the GI protection system, and the packaging bears the GI mark. The other is boiled Shirasu from Shizuoka Prefecture that has not been certified under the GI protection system." For respondents answering they would purchase the Tagonoura Shirasu, the additional permissible WTP was inquired: "Considering your situation and your household, and comparing Tagonoura Shirasu boiled Shirasu which has been certified with the GI logo with other boiled Shirasu from Shizuoka Prefecture, up to what percentage difference in price would you continue to choose to purchase the Tagonoura Shirasu?" Additionally, respondents were informed that one pack of boiled Shirasu from Shizuoka Prefecture, which had not received GI certification $(60 \mathrm{~g})$, was 300 yen. With reference to $[18,19]$; and [20]; the available choices for the difference in the price were less than $3 \%$, more than $3 \%$ but less than $5 \%$, more than $5 \%$ but less than $10 \%$, more than $10 \%$ but less than $15 \%$, more than $15 \%$ but less than $20 \%$, more than $20 \%$ but less than $25 \%$, more than $25 \%$ but less than $30 \%$, more than $30 \%$ but less than $50 \%$, and more than $50 \%$ (nine categories).

\subsection{Method of analysis and data}

Of the 1000 collected responses, after excluding the resistant response sample, 889 were used in the analysis (i.e., an effective response rate of $88.9 \%$ ). Resistant responses were considered those who did not wish to purchase Tagonoura Shirasu for reasons 


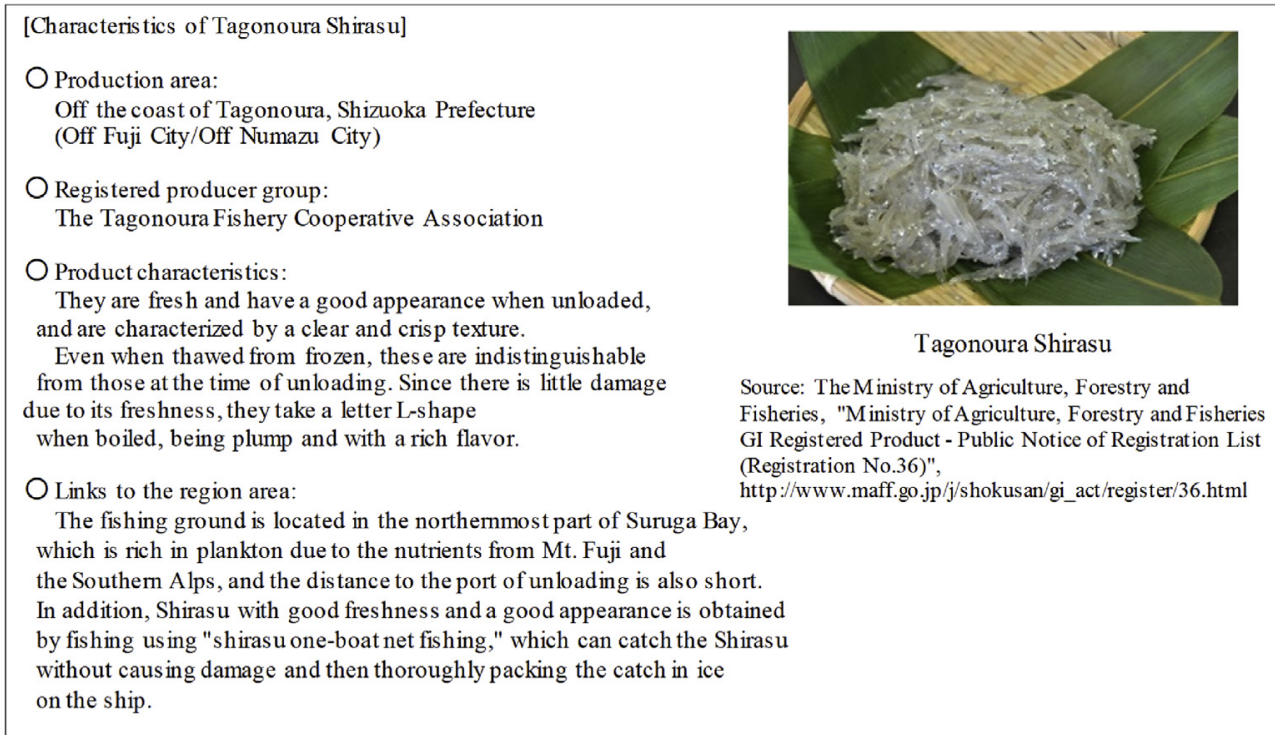

Fig. 3. Explanation of Tagonoura Shirasu in the survey.

Table 3. Variable definitions.

\begin{tabular}{|c|c|c|c|c|}
\hline Variable & & Definition & $\begin{array}{l}\text { Number of } \\
\text { responses }\end{array}$ & Frequency \\
\hline \multirow[t]{2}{*}{ SHIRA } & \multirow[t]{2}{*}{ Purchased Shirasu within the past year } & $1=$ yes & 185 & $20.8 \%$ \\
\hline & & $0=$ otherwise & 704 & $79.2 \%$ \\
\hline \multirow[t]{5}{*}{ CHEAPER } & \multirow[t]{5}{*}{ Purchases food as cheaply as possible } & $1=$ disagree & 51 & $5.7 \%$ \\
\hline & & $2=$ somewhat disagree & 110 & $12.4 \%$ \\
\hline & & $3=$ neither agree or disagree & 232 & $26.1 \%$ \\
\hline & & $4=$ somewhat agree & 294 & $33.1 \%$ \\
\hline & & $5=$ agree & 202 & $22.7 \%$ \\
\hline \multirow[t]{2}{*}{ FRESH } & \multirow{2}{*}{$\begin{array}{l}\text { Emphasizes freshness when purchasing } \\
\text { seafood }\end{array}$} & $1=$ emphasizes & 356 & $40.0 \%$ \\
\hline & & $0=$ otherwise & 533 & $60.0 \%$ \\
\hline \multirow[t]{5}{*}{ LEVEL } & \multirow[t]{5}{*}{$\begin{array}{l}\text { The level of awareness of the name of the } \\
\text { production area when purchasing seafood }\end{array}$} & $\begin{array}{l}1=\text { does not care at all about the production area, } \\
\text { be it domestic or foreign }\end{array}$ & 271 & $30.5 \%$ \\
\hline & & $2=$ prefers domestic production & 434 & $48.8 \%$ \\
\hline & & $3=$ cares about the name of the prefecture & 139 & $15.6 \%$ \\
\hline & & $\begin{array}{l}4=\text { cares about the names of municipalities in the } \\
\text { area and the names of fishing ports }\end{array}$ & 22 & $2.5 \%$ \\
\hline & & $5=$ cares about the producer name & 23 & $2.6 \%$ \\
\hline \multirow[t]{5}{*}{ KASSEI } & \multirow{5}{*}{$\begin{array}{l}\text { Purchases food linked to the revitalization } \\
\text { of production areas and regions }\end{array}$} & $1=$ disagree & 63 & $7.1 \%$ \\
\hline & & $2=$ somewhat disagree & 150 & $16.9 \%$ \\
\hline & & $3=$ neither agree or disagree & 390 & $43.9 \%$ \\
\hline & & $4=$ somewhat agree & 226 & $25.4 \%$ \\
\hline & & $5=$ agree & 60 & $6.7 \%$ \\
\hline \multirow[t]{3}{*}{ GININCHI } & \multirow{3}{*}{$\begin{array}{l}\text { To what extent do you know about the } \\
\text { GI protection system? }\end{array}$} & $1=$ Not at all & 676 & $76.0 \%$ \\
\hline & & $2=\mathrm{I}$ know only the term & 139 & $15.6 \%$ \\
\hline & & $3=\mathrm{I}$ know the term and what it means & 74 & $8.3 \%$ \\
\hline \multirow[t]{2}{*}{ GENDER } & \multirow[t]{2}{*}{ Gender } & $1=$ male & 303 & $34.1 \%$ \\
\hline & & $0=$ female & 586 & $65.9 \%$ \\
\hline \multirow[t]{7}{*}{ INCOME } & \multirow[t]{7}{*}{ Household annual income } & $100=$ less than 2 million yen & 117 & $13.2 \%$ \\
\hline & & $300=2-4$ million yen & 249 & $28.0 \%$ \\
\hline & & $500=4-6$ million yen & 210 & $23.6 \%$ \\
\hline & & $700=6-8$ million yen & 144 & $16.2 \%$ \\
\hline & & $900=8-10$ million yen & 88 & $9.9 \%$ \\
\hline & & $1250=10-15$ million yen & 58 & $6.5 \%$ \\
\hline & & $1750=15$ million yen or over & 23 & $2.6 \%$ \\
\hline
\end{tabular}




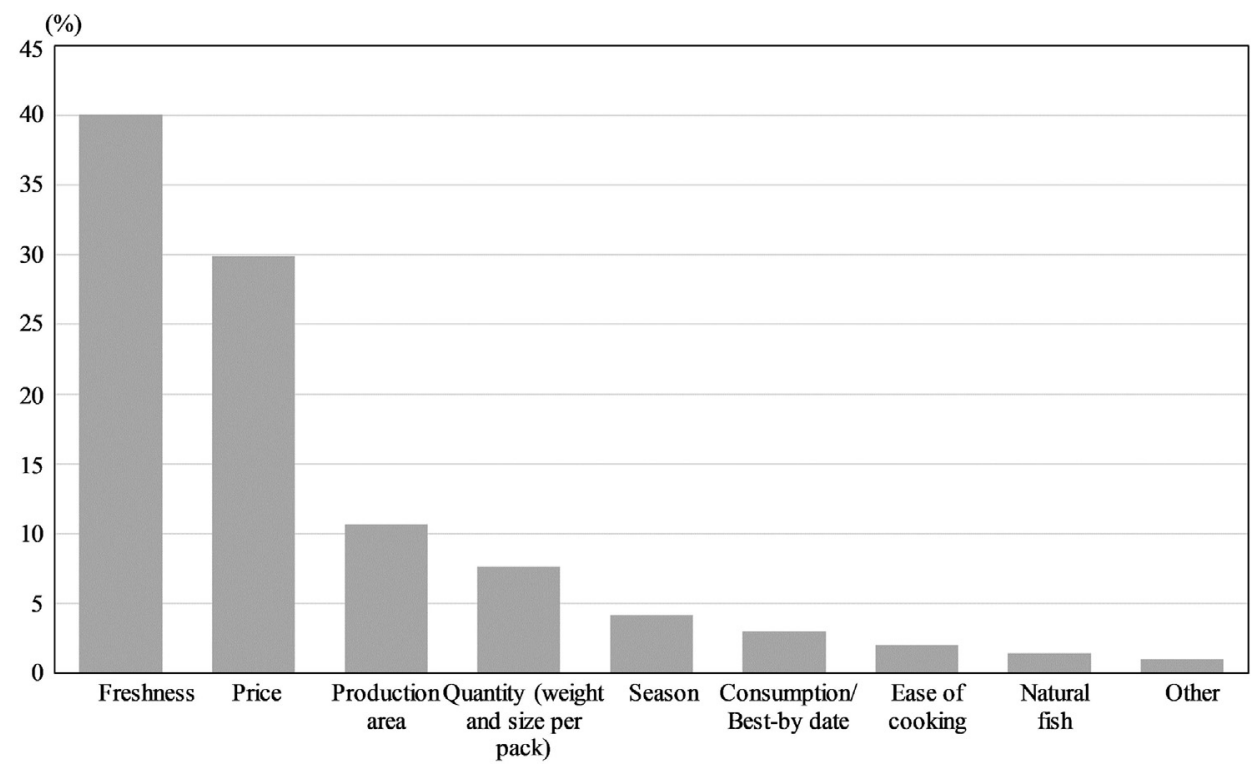

Fig. 4. Points emphasized when purchasing seafood. Note: $n=889$.

that bore no relation to WTP, such as not understanding the question.

The available choices for the price difference (relatively high) were presented as WTP brackets that included the respondent's WTP. By taking the midpoint of the bracket as the respondent's WTP, it was possible to apply ordinary least squares (OLS). However, where the respondent's expected WTP value was not equal to the midpoint of the brackets presented, applying OLS will engender estimate biases [21].

We therefore applied a grouped data regression model, in which each available price difference (relatively high) option had a bracket; in other words, it was possible to estimate the aggregated WTP valuation function [18-22]. The valuation function was established as follows:

$\ln W T P_{i}=\alpha+\chi_{i}^{\prime} \beta+\epsilon_{i}$.

Here, WTP $\mathrm{P}_{\mathrm{i}}$ is the WTP of respondent $i, \alpha$ a constant term, $\chi_{i}$ the attribute column vector for
Table 5. Distribution of respondents' WTP $(n=889)$.

\begin{tabular}{llll}
\hline Interval & WTP $($ Yen $/ 60 \mathrm{~g})$ & $\begin{array}{l}\text { Number of } \\
\text { responses }\end{array}$ & Distribution \\
\hline $0-3 \%$ & $0 \leq \mathrm{WTP}<9$ & 309 & $34.8 \%$ \\
$3-5 \%$ & $9 \leq \mathrm{WTP}<15$ & 128 & $14.4 \%$ \\
$5-10 \%$ & $15 \leq \mathrm{WTP}<30$ & 195 & $21.9 \%$ \\
$10-15 \%$ & $30 \leq \mathrm{WTP}<45$ & 120 & $13.5 \%$ \\
$15-20 \%$ & $45 \leq \mathrm{WTP}<60$ & 61 & $6.9 \%$ \\
$20-25 \%$ & $60 \leq \mathrm{WTP}<75$ & 33 & $3.7 \%$ \\
$25-30 \%$ & $75 \leq \mathrm{WTP}<90$ & 16 & $1.8 \%$ \\
$30-50 \%$ & $90 \leq \mathrm{WTP}<150$ & 18 & $2.0 \%$ \\
More than $50 \%$ & $150 \leq \mathrm{WTP}$ & 9 & $1.0 \%$ \\
\hline
\end{tabular}

each explanatory variable, $\beta$ the coefficient column vector of $\chi_{i}$, and $\epsilon_{i}$ independent and expresses the error term that follows a normal distribution with mean of zero and variance $\sigma^{2}$. Parameters were estimated using the maximum likelihood method, with the average value of $W T P$ being $\exp \left(\widehat{\alpha}+\chi_{i}^{\prime} \widehat{\beta}+\right.$ $\left.\sigma^{2} / 2\right)$ and the median value $\left(\widehat{\alpha}+\chi_{i}^{\prime} \widehat{\beta}\right) . \wedge$ represents the estimated value of the parameter.

Table 4. Methods to obtain information about the geographical indications of Tagonoura Shirasu desired by respondents.

\begin{tabular}{lll}
\hline Item & $\begin{array}{l}\text { Number of } \\
\text { responses }\end{array}$ & $\begin{array}{c}\text { Percentage } \\
\text { Display information on the tray pack }\end{array}$ \\
Display information at the store & 353 & $39.7 \%$ \\
Display on devices such as touch panels & 264 & $29.7 \%$ \\
Information can be obtained on smartphones or computers & 29 & $3.3 \%$ \\
You can ask the store clerks for information & 17 & $3.3 \%$ \\
If it has obtained the GI certification (GI mark), then there is no need to know further information & 43 & $1.9 \%$ \\
Other & 154 & $4.8 \%$ \\
Total & 889 & $17.3 \%$ \\
\hline
\end{tabular}


Table 6. Result of the grouped data regression model.

\begin{tabular}{llll}
\hline Variable & Estimated value & SE & Mean \\
\hline SHIRA & $0.2933^{* * *}$ & 0.0977 & 0.7919 \\
CHEAPER & $-0.1100^{* * *}$ & 0.0338 & 3.5467 \\
FRESH & $0.2095^{* * *}$ & 0.0771 & 0.4004 \\
LEVEL & $0.1304^{* * *}$ & 0.0432 & 1.9786 \\
KASSEI & $0.1076^{* * *}$ & 0.0387 & 3.0787 \\
GININCHI & $0.1719^{* * *}$ & 0.0596 & 1.3228 \\
GENDER & $0.1607^{* *}$ & 0.0805 & 0.3408 \\
INCOME & $0.0003^{* * *}$ & 0.0001 & 544.6007 \\
CONST & $0.6053^{* * *}$ & 0.2274 & \\
$\sigma$ & $1.0319^{* * *}$ & 0.0335 & \\
\hline Sample size & 889 & & \\
Maximum log-likelihood & -1528.4692 & & \\
Mean WTP & $8.2445 \%$ & & \\
Median WTP & $4.8413 \%$ & & \\
\hline Note: & and & & \\
\hline
\end{tabular}

Note: $* *$ and $* * *$ denote statistical significance at the $5 \%$ and $1 \%$ levels, respectively.

The explanatory variables include the frequency of purchasing ingredients and fresh fish, points emphasized when purchasing seafood, conscientiousness and behavior when purchasing seafood, extent of awareness of the Japanese GI protection system and expected effects, as well as the personal attributes of the respondent.

\section{Results}

Among the candidate explanatory variables in section 2.3 and as subsequently described, the characteristic points of survey response results $(n=889)$ are explained using the results from the grouped data regression model, focusing on statistically significant variables (Table 3 ).

Within the past year, $20.8 \%$ of respondents had purchased Shirasu (SHIRA). Unlike livestock, there are many types of seafood and, with about $20 \%$ of respondents having purchased Shirasu within the past year, the frequency of Shirasu purchase by consumers cannot be considered low. Overall, $55.8 \%$ of respondents answered "true" or "somewhat true" to purchasing food as cheaply as possible (CHEAPER). In other words, more than half of respondents are conscious of price when purchasing food.

Regarding the level of awareness of the name of the production area when purchasing seafood, $48.8 \%$ of respondents preferred domestically produced products, while this choice extended to the names of producers for just $2.6 \%$ of respondents (LEVEL). In other words, when purchasing seafood at the supermarket, respondents typically emphasize whether the products were domestically produced and few respondents emphasized more detailed production information.
Overall, $32.1 \%$ of respondents responded with "true" or "somewhat true" to the statement that purchasing foodstuffs is linked to the revitalization of the producer area or region (KASSEI). In other words, for more than half of the respondents, the revitalization of producer areas and regions is not a source of motivation when purchasing food.

Regarding the level of awareness of the GI protection system, $76.0 \%$ of respondents did not know about it (GININCHI). Only $8.3 \%$ of respondents knew both the term and its significance. Only $8.3 \%$ of respondents knew both the term and its significance. At the time this survey was carried out (October 2018), about three years had passed since the start (June 2015) of the Japanese GI protection system, which means the extent of respondents' awareness of the system can be said to be low.

Table 3 shows the responses regarding freshness as a point emphasized when purchasing seafood $(F R E S H)$. In the survey, the respondents selected the most important points from among nine items: production area, quantity, freshness, price, season, natural fish, consume by/expiration date, ease of cooking, and others (Fig. 4). Among the nine items, the most important $(\%)$ were freshness, $(40.0 \%)$, price $(29.9 \%)$, and production area $(10.7 \%)$. In other words, respondents placed the highest emphasis on freshness when purchasing seafood. In previous studies, most respondents also emphasized freshness when purchasing fresh fish [23] and vegetables [19]. When purchasing fresh ingredients, such as seafood and vegetables, consumers are thought to place the highest emphasis on freshness. Furthermore, the order of priorities when purchasing fresh fish and vegetables, like the results of this paper's analysis and in order starting with the highest percentage share, are freshness, price and production area.

Table 4 shows the methods by which respondents wished to obtain information about Tagonoura Shirasu's geographical indication (e.g., production area, product characteristics, ties to the region). Most respondents wanted information to be displayed on the tray packaging $(39.7 \%)$, followed by displaying information within the store $(29.7 \%)$. Few respondents wished to obtain information by other means. In other words, rather than act independently by using a computer or inquiring from store clerks to obtain information about geographical indication, respondents wished to be able to obtain such information when shopping easily and directly.

We explain the results on respondents' additional permitted WTP (\%) by comparing Tagonoura Shirasu to Shizuoka Prefecture's boiled Shirasu, which 
has not received certification under the GI protection system (300 yen/60 g) (Table 5). Respondents with a WTP of $3 \%$ or less (9 yen $/ 60 \mathrm{~g}$ ) were most numerous, at $34.8 \%$. Respondents with a WTP of $15 \%$ or less (45 yen/60 g) comprised $84.6 \%$ of respondents, with few respondents being willing to pay more than a $15 \%$ price premium.

Table 6 shows the results of applying a grouped data regression model to the characteristics of the consumers that evaluate the economic value of Tagonoura Shirasu highly. For consumer characteristics, were eight parameters were statistically significant at the $1 \%$ or $5 \%$ levels.

SHIRA, FRESH, CHEAPER, LEVEL, and KASSEI are the variables concerning awareness and behavior when respondents usually purchase food. SHIRA, FRESH, LEVEL, and KASSEI are positive, and the more frequently a respondent has purchased Shirasu within the past year, the greater the emphasis he/she places on freshness when purchasing seafood was, the greater awareness of detailed production standards when purchasing seafood and the more respondents purchased foodstuffs linked to the revitalization of producer areas and regions, the higher their WTP was. CHEAPER was negative, meaning the less regard a respondent showed for price when purchasing foodstuffs, the higher their WTP. In previous research, consumers who are conscious of purchasing food as cheaply as possible tend to value the added value of certified foodstuffs lowly [24]. The negative result for CHEAPER is therefore consistent with these previous results.

Among the variables concerning the assessment of the Japanese GI protection system, GININCHI is statistically significant and positive, meaning that the more a respondent knew details about the GI protection system, the higher their WTP was.

GENDER and INCOME are variables related to the personal attributes of respondents. Both are positive, with males and respondents with high annual household incomes having a high WTP.

The additional average WTP for Tagonoura Shirasu, measured based on the results of the grouped data regression model, was around $8.2 \%$. In other words, the WTP of the Tagonoura Shirasu certified under the GI protection system was around 8.2\% higher than that of the uncertified Shizuoka Prefecture Shirasu. We assumed in the survey that the price of Shizuoka Prefecture's boiled Shirasu, which had not been certified under the GI protection system, was 300 yen $/ 60 \mathrm{~g}$. As a result, respondents were found to remain willing to purchase Tagonoura Shirasu at a price around 24.7 yen higher (about $8.2 \%)$, that is, at 324.7 yen.

\section{Discussion}

Tagonoura Shirasu was evaluated as having an average WTP $8.2 \%$ higher than Shizuoka Prefecture's Shirasu, which had not been certified under the GI protection system (Table 6). This result is not particularly high compared to the average price premium of $16 \%$ for marine products registered under the EU GI system [11]. However, the Japanese GI protection system has been only recently launched and its recognition is still low (Table 3).

InJapanese fisheries policy, the 2017 Basic Fisheries Plan promotes the efforts to protect the brand value of high-quality marine products by using the GI protection system [13]. To promote the protection of regional brands using the GI protection system, from an economic perspective, producers must be able to achieve value-added sales and increase their incomes by registering marine products in the system. As stated above, the [2] points out that registering agricultural products under the GI protection system mainly has price increasing effects.

From our analysis, the consumers with a high WTP for Tagonoura Shirasu are those that have purchased Shirasu within the past year (SHIRA), emphasize freshness when purchasing seafood $(F R E S H)$, have more detailed knowledge of production area standards when purchasing seafood (LEVEL), purchase foodstuffs linked to the revitalization of production areas and regions (KASSEI), have little regard for purchasing the cheapest possible foodstuffs (CHEAPER), have more knowledge on the GI protection system (GININCHI), are male (GENDER), and have a high annual household income (INCOME) (Table 6). In the future, it is thought that appealing Tagonoura Shirasu targeting consumers with a high WTP will be effective in promoting Tagonoura Shirasu.

For example, 1) the more detailed a respondent's knowledge of the GI protection system (GININCHI), the higher their WTP for Tagonoura Shirasu is. In other words, to increase the WTP for Tagonoura Shirasu, it is important to first enable consumers to understand the GI protection system and its characteristics (Table 3). 2) The greater the emphasis placed on freshness by a respondent when purchasing seafood (FRESH), the higher their WTP for Tagonoura Shirasu is. It is therefore important to appeal strongly to consumers that Tagonoura Shirasu has a high degree of freshness due to its production method (Table 2), product characteristics, as well as its links to the local region (Table 4). 3) The higher the respondents' awareness of detailed production area standards (LEVEL) and their purchase 
of foodstuffs linked to the revitalization of production areas and regions (KASSEI), the higher their WTP for Tagonoura Shirasu is. Therefore, there are effects in addition to the fact that the GI protection system can protect regional brands, Tagonoura Shirasu's characteristics (production area, registered producer group, product characteristics and links to the region) can strongly appeal to consumers by emphasizing who made the product, where it was made, and how it was made (Table 4).

Shirasu is not only caught in a particular area in Japan, but in various regions. Moreover, it is caught naturally and it is thus difficult to control production using techniques such as improved feed as with farmed fish. Therefore, in addition to the high degree of freshness of Tagonoura Shirasu, it is thought that strong emphasis of it being a regional brand with tradition and characteristics nurtured within a specific region, as well as how it is differentiated from the Shirasu in other regions, will be effective in the appeal to consumers. A such, utilizing the characteristics of consumers with a high WTP for Tagonoura Shirasu in this study is expected to contribute to increased incomes for producers and the spread of the GI protection system.

\section{Acknowledgements}

This paper is the outcome of a research project funded by the Japan Fisheries Research and Education Agency, Japan (FRA).

\section{Conflict of interest statement}

The authors declare no conflict of interest.

\section{References}

[1] Matsuda Y. Institutional study of the regional brand protection system in Japan. Doctoral thesis. Japan: Ritsumeikan University; 2015. p. 4 [in Japanese].

[2] Ministry of Agriculture, Forestry and Fisheries. What are geographical indications?. 2019 [in Japanese], http://www. maff.go.jp/j/shokusan/gi_act/outline/index.html. [Accessed 15 February 2019].

[3] Ministry of Agriculture, Forestry and Fisheries. Establishing a geographical indication protection system in Japan-comparison with the EU system and regional collective trademark system and future use for regional brand creation. 2014 [in Japanese], http://www.maff.go.jp/primaff/ koho/seminar/2014/attach/pdf/141111_02.pdf. [Accessed 5 June 2019].

[4] Sekine K. What is the roles of the geographical indication system in Japan? Agriculture and Economy 2015;81(12): 62-70 [in Japanese].

[5] Naito Y. Protection of geographical indications. Policy research institute. Ministry of Agricultural, Forestry and Fisheries (PRIMAFF) Review 2017;77:10-1 [in Japanese].

[6] London Economics. Evaluation of the CAP policy on protected designations of origin (PDO) and protected geographical indications (PGI)-final report. 2008. https://londoneconomics. co.uk/blog/publication/evaluation-of-the-cap-policy-onprotected-designations-of-origin-pdo-and-protectedgeographical-indications-pgi/. [Accessed 12 January 2019].

[7] Kimura Y. Chapter 4: deployment in Europe Agricultural, forestry and fishery production area brand strategy. Tokyo. In: Kosaka R, Gyosei, editors. Regional regeneration through geographical indications; 2015. p. 61-78 [in Japanese].

[8] Defrancesco E, Kimura J. Are geographical indications (GIs) effective value-adding tools for traditional food? Insights from the new-born Japanese GIs system. Proceedings of System Dynamics and Innovation in Food Networks 2018:119-30.

[9] Deselnicu OC, Costanigro M, Souza-Monteiro DM, McFadden DT. A meta-analysis of geographical indication food valuation studies: what drives the premium for originbased labels? J Agric Resour Econ 2013;38(2):204-19.

[10] Loureiro ML, McCluskey JJ. Assessing consumer response to protected geographical identification labeling. Agribusiness 2000;16(3):309-20.

[11] Chever T, Renault C, Renault S, Romieu V. Value of production of agricultural products and foodstuffs, wines, aromatised wines and spirits protected by a geographical indication (GI). Final report. 2012. https://ec.europa.eu/ agriculture/sites/agriculture/files/external-studies/2012/ value-gi/final-report_en.pdf. [Accessed 10 January 2019].

[12] Defrancesco E. Is the European Union Geographical Indications (GI) system an effective value-adding framework for food and foodstuffs? Some Insights into the Italian GIs. In: Ministry of agriculture, forestry and fisheries GI symposium, held january 17, 2017; 2017.

[13] Ministry of Agriculture, Forestry and Fisheries. New basic plan for fisheries. 2017 [in Japanese], http://www.jfa.maff.go. jp/j/policy/kihon_keikaku/. [Accessed 20 November 2019].

[14] Ministry of Agriculture, Forestry and Fisheries. Sea fisheries statistical survey. 2019 [in Japanese], http://www.maff.go.jp/ $\mathrm{j} /$ tokei/kouhyou/kaimen_gyosei/. [Accessed 5 October 2019].

[15] The Japanese Society of Fisheries Science. Dictionary for fisheries science. Tokyo: Koseisha-koseikaku; 1989. p. 103 [in Japanese].

[16] Tamotsu S, Fujita S, Ogata Y, Kimura I. Postmortem autolysis of juvenile sardines during cold storage. Nippon Suisan Gakkaishi 2018;84(1):103-10 [in Japanese, with English abstract].

[17] Ministry of Agriculture, Forestry and Fisheries. Ministry of agriculture, forestry and fisheries GI registered productpublic notice of registration list (registration No. 36) Tagonoura Shirasu. 2017 [in Japanese], http://www.maff.go.jp/j/ shokusan/gi_act/register/36.html. [Accessed 5 June 2019].

[18] Iwamoto H, Sato K, Sawada M. Consumer evaluation of beef traceability. In: Sawada M, editor. Economic evaluation of food safety-stated preferences approach. Tokyo, Japan: Association of Agriculture and Forestry Statistics; 2004. p. 174-97.

[19] Yamamoto Y, Sajiki T, Sawauchi D, Masuda K, Tokoro S, Iwamoto $H$. Japanese consumer Willingness to Pay for locally produced agricultural products: using data obtained from a consumer survey conducted at a supermarket with "shop in shop. Hokkaido Journal of Agricultural Economics 2009;14(2):77-83 [in Japanese].

[20] Sajiki T, Lu Y-H. Consumer evaluation of Japanese Miyagi Prefecture farmed oysters after the introduction of a traceability system. J Fish Soc Taiwan 2019;46(3):135-42.

[21] Terawaki T. Analysis of environmental evaluation of agriculture. Tokyo: Keiso Shobo; 2002 [in Japanese].

[22] Cameron TA, Huppert DD. OLS versus ML estimation of non-market resource values with payment card interval data. J Environ Econ Manag 1989;17(3):230-46.

[23] Sajiki T, Tamaki Y, Shimizu I. Analysis of consumer evaluations of locally produced seafood-a case study of a direct sales office in Yokohama. North Japan Fisheries 2010;38: 69-78.

[24] Katoh M, Terawaki T, Fukushima A. Consumer's willingness to pay for stable supply of traditional vegetable crops-a case study of Welsh onion "Iwatsu" of Hyogo Prefecture. Japanese Journal of Farm Management 2007;45(1):73-8 [in Japanese]. 